Historic, Archive Document

Do not assume content reflects current scientific knowledge, policies, or practices. 



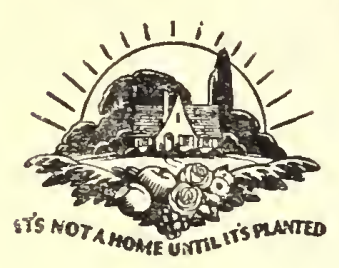

THE CHAS. FRANKE NURSERIES

NURSERYMEN AND FLORISTS

BELL PHONE

EVERGREEN SPECIALISTS

NURSERIES: AT FISHER, N. J., ON W. J. \& S. R. R.

BERLIN 222-R-6

P. O. WATERFORD WORKS, N. J.

TERMS CASH

\section{Rare Cacti and Succulents}

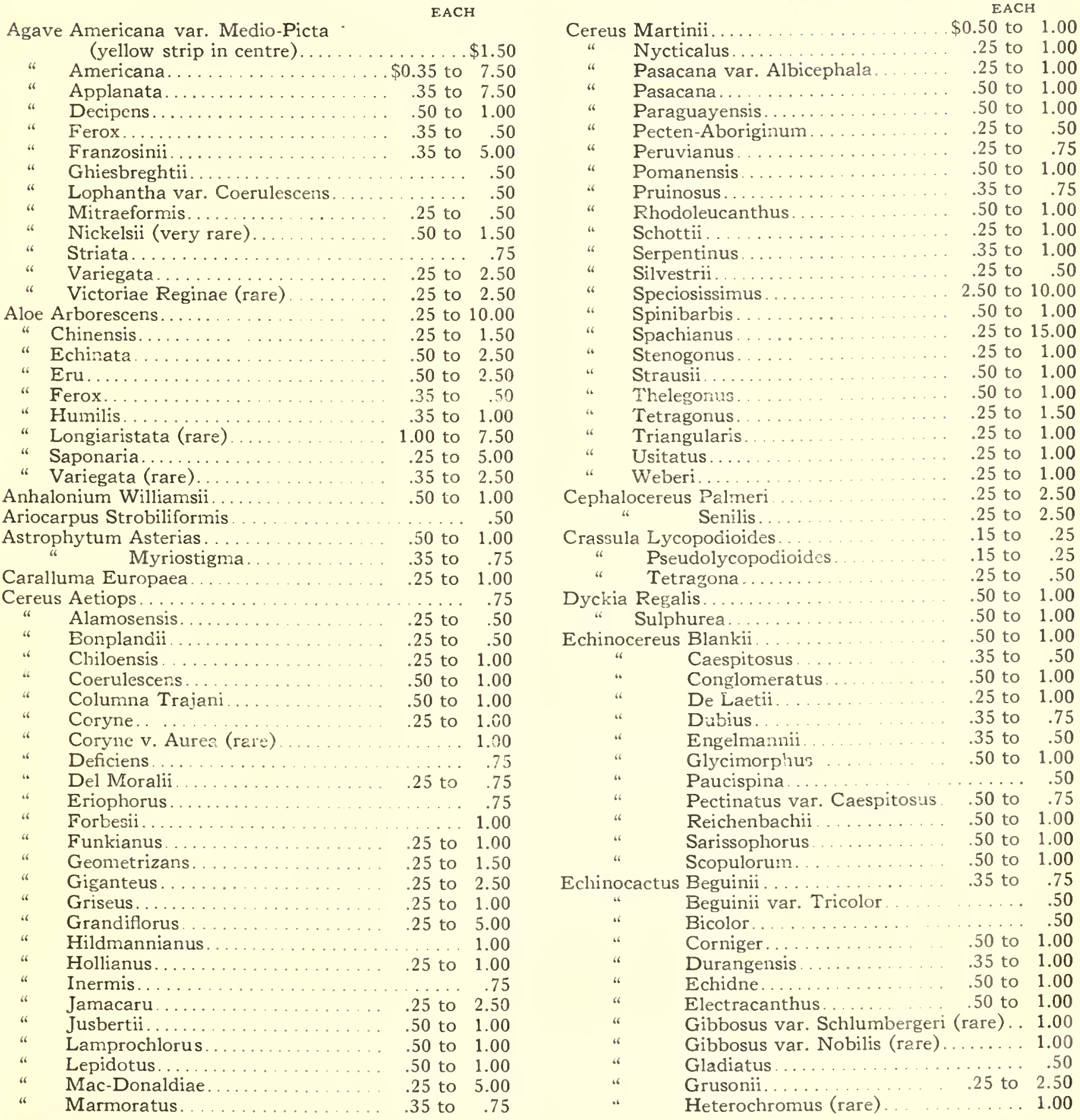


$\mathrm{EACH}$

Echinocactus Hexaedrophorus......... \$0.50 to $\$ 1.00$

Ingens.................... 1.00

Ingens var. Saltillensis..... . .25 to $\quad .75$

Ingens var. Visnaga....... .50 to 1.00

Knebelii (rare).............. 1.00

Lamellosus.... . . . . . . . . . . .50 to 1.00

Leucacanthus............ .50 to 1.00

Lenninghausii (rare)...... .50 to 1.00

Longihamatus var. Papyra-

canthus........................... 1.00

Lophothele............. . .35 to .75

Mathssonii.................... . .50

Minusculus. . . . . . . . . . . . . . . .50

Mihanovichii (very rare). ....... 1.00

Nidulans................. . . . 50

Pentacanthus........... .50 to 1.00

Phyllacanthus................. . .50

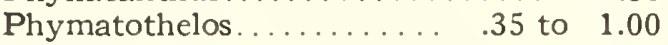

Pilosus. . . . . . . . . . . . . . . . .50

Quehlianus.................... . .50

Rafaelensis... . . . . . . . . . . . . . . .50

Recurvus............... .25 to 1.00

Roseanus. . . . . . . . . . . . . . . . . . . . 50

Saueri................ . .35 to .75

Saussieri............... . .50 to 1.00

Scheeri.................. 50 to 1.00

Schmiedickeanus (very rare) ...... 1.00

Setispinus var. Cachetianus. .50 to 1.00

Townsendianus.......... 50 to 1.00

Trollietii.............50 to 1.00

Uncinatus............... . .25 to .75

Uncinatus v. Wrightii ..... . .35 to 1.00

Viridescens............. .25 to 1.00

Violaciflorus . . . . . . . . . . . . . . . . . .50

Wagnerianus............. . .35 to .75

Wislizenii...........2.50 to 5.00

Echinopsis Aurea.................. . .50 to 1.00

Campylacantha.......... .25 to 1.00

Campylacantha v. Cordobensis (rare). . 1.00

Decaisneana.............. .50 to 1.00

Ducis Pauli (very rare). . . . . . . . . . . 2.50

Eyriesii................. . .50 to 1.00

Formosa............... .50 to 1.00

Formosissima........... .50 to 1.00

Gemmata............... . 50 to 1.50

Graulichii (very rare)............ 2.50

Leucantha............. . .25 to .75

Multiplex............... .50 to 1.00

Mulleri................. .50 to 1.00

Oxygona................ .25 to 1.00

Paraguayensis............ . .50 to 1.00

Rhodacantha............. .25 to 1.00

Rhodotricha v. Argentiniensis

(very rare) .................. 1.00

Schelhasei............ . .50 to 1.00

Schickendantzii (rare)............ 1.00

Shafferi (very rare) . ............. 2.50

Staffeni (very rare)............. 2.50

Spiniflora ................ 50 to 1.00

Triumphans............ .25 to 1.00

Tubiflora................ .25 to 1.00

Valida.................. .50 to 1.00

Wilkensii................ .50 to 1.00

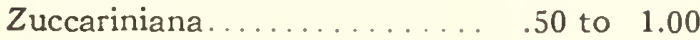

Echeveria Agavoides................ . .35 to 1.00

Desmetiana............. .25 to 1.00

Globosa................... . .15 to .50

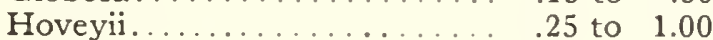

Manda's Giant............ 1.00 to 5.00
Echeveria Mettalica............

$\mathrm{EACH}$

$\$ 0.50$ to $\$ 1.00$

Pubescens................. . .15 to .50

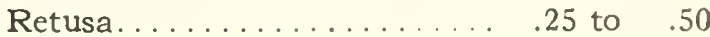

Setosa................. 50 to 1.00

Wienbergii.........................

Euphorbia Canariensis................................... to 1.00

" Cerieformis..............50 to 1.00

" Lactea................ 1.00 to 5.00

“ Mammillaris............ .50 to 1.00

“ Obesa (very rare) .......... 1.00 to 2.50

“ Tiruacallii............... 50 to 1.00

Gasteria Angulata................. . . . . . . . . . . . . . . . . . . . .

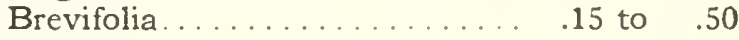

Carinata................ .25 to .50

Columbrina ............... .25 to .50

Dicta.................. . .25 to .50

Disticha Angulata............ . .25 to .50

Echinata Glauca............. .25 to .50

Echinata................. .25 to .50

Glabra.................... . .25 to .50

Intermedia............... .25 to .50

Latifolia . . . . . . . . . . . . . . . . .25 to .50

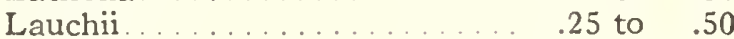

Lingua.................... . . . . . 50

Maculata................... . .25 to .50

Marmorata Minima......... .25 to .50

Minima.................. .25 to .50

Nitida..... .35 to .50

Obtusifolia .................25 to . .50

Planifolia.................. . .25 to .50

Prolifera.................... .25 to .50

Scabberima ................ . .25 to .50

Trigona..................... .25 to .50

Verrucosa.... .25 to 1.00

Haworthia Attenuata.................. . . . . . . .

Coarctata............. .75

Cuspidata... .35 to .75

Cymbiformis .................... 35 to .50

Fasciata (rare)............... .75 to 1.00

Glabrata Concolor........... .25 to 1.00

Laetevirens............. . . . . . to .50

Lineata................. . . . . . .50

Margaritifera................75 to 1.00

Pallida............... . .50 to .75

Pseudo Rigida... . . . . . . . . . . .35 to 1.00

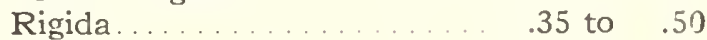

Rugosa................. . .50 to 1.00

Tessellata (rare) $\quad .50$ to 1.50

Turgida (rare) ............ . . .50 to 1.00

Viscosa................. .25 to 1.00

Huernia Schneideriana.

Leuchtenbergia Principis

.25 to 1.00

.50 to 1.00

Mamillaria Albicans. . . . . . . . . . . . . . . . . . .50

Angularis...... .25 to 1.00

Angularis v. Compressa..... . .50 to .75

Bicolor

Candida................................ 15 to

Candida var. Rosea.

Centricirrha

Ceratites.

Chionocephala

Cirrhifera Longispina

Clava

Compressa

Cornifera.

Crassispina

Dealbata.

Decipiens

Dioica.

.... .50

25 to 1.00

.35 to .50

.35 to .50

.75

.25 to 1.00

.35 to .50

... .75

.50

.50 to .75

.50 to .75 
EACH

Mamillaria Durispina

$\$ 0.25$ to $\$ 1.00$

Echinoidea.............. .25 to 1.00

Gladispina................. . .50

Grandiflora........................ 1.00

Gulzowiana (rare)................ 1.00

Hahniana (very rare)....... .50 to 2.50

Heyderi var. Hemisphaerica.. .50 to 1.00

Jaumavensis................. . . 35

Leona.................\$0 ..... .35

Longimamma............. .50 to 1.00

MacDougalii............. .50 to 1.00

MacDowellii................... .50

Macracantha.................... $\quad .75$

Melanocentra................. .75

Meiacantha.............. .35 to 1.00

Micromeris Greggi................ . .50

Micromeris ............. .50 to 1.00

Palmeri var. Jaumavei...... . .50 to 1.00

Parkinsonii.................... . .50

Pectinata..................... . .50

Pfeifferi................ 25 to 1.00

Plumosa............... .50 to 1.00

Pusilla.................. .25 to .75

Radians................. . .35 to .75

Recurvispina............ . . 35 to .50

Rhodantha ..............25 to 1.00

Rhodantha var. Fuscata..... . .50 to 1.00

Ritteriana (rare).......... . .50 to 1.00

Roseo-Alba................ . .35 to .75

Shiedeana (very rare) ....... . . 50 to 1.00

Spinosissima v. Atrosanguinea .35 to 1.00

Spinosissima . . . . . . . . . . . . .35 to .50

Vaupeliana............... .35 to 1.00

Winteriae ........................ 15 to 1.00

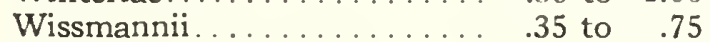

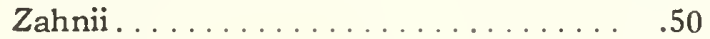

Zeyeriana.................35 to .75

Melocactus Amoenus................ . . .50 to 1.00

Caesius.............. . 50 to 1.00

Communis ................50 to 1.00

Neyri............... 50 to 1.00

Mesembrianthemum Cephalophylium Confusum

Cheiridopsis Caroli-

Schmidtii........... . .50

Faucaria Haagei

(rare)........ 1.00 to 2.50

Faucaria Tigrina.... .25 to .75

Faucaria Tigrina Su-

perba.............. .35 to 1.00

Lithops Bella (rare) . 50 to 1.00

Lithops Lesliei... .35 to 1.00
Mesembrianthemum Lithops Pseudotrun-

$\mathrm{EACH}$ catella........\$ $\$ 0.50$ to $\$ 1.00$

Lithops Pseudotruncatella var. Mundtii .50 to 1.00

Obregonia Denegrii (rare)..........\$0.50 to 1.00

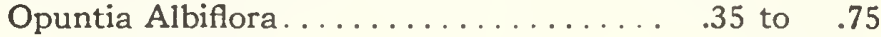

Basilaris..................25 to 1.00

Cereiformis...............50 to 1.00

Invicta (new) .............. .25 to .50

Microdasys................ .25 to 1.00

Monacantha Variegata......... .50 to 1.00

Tuna......................... 50 to 5.00

Phyllocactus Mixed Named Varieties.... . . 25 to $\quad .50$

Pelecyphora Asseliformis (rare)........ . . 50 to 1.00

Pilocereus Albispinus................. .25 to .50

" Celsianus var. Rubriflora.......... 1.00

" Chrysomallus................ 1.00

“ Chrysacanthus............. .25 to .50

" Colombianus............ .50 to 1.00

" Erythrocephalus...........50 to 1.00

" Euphorbioides............ .50 to 1.00

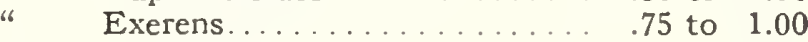

“ Moritzianus................... 1.00

" Polylophus ....................... 50 to 1.00

“ Robinii............... .50 to 1.00

" Russelianus............... .50 to 1.00

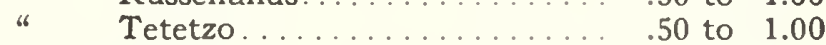

Stapelia Anguinea. . . . . . . . . . . . . . . .20 to .50

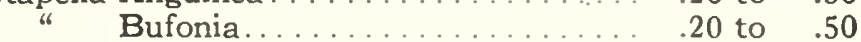

“ Bufonia Variegata........... .20 to .50

" Chaybdis............... .25 to .50

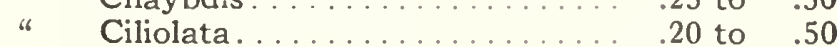

“ Conspurcata............... 20 to .50

" Depressa................. .20 to .50

“ Gigantea.......................... 25 to 1.50

" Hanburyana............. .25 to .50

“ Hirsuta................... . .20 to .50

" Hispida.................... .25 to $\quad .50$

“ Luxurians. . . . . . . . . . . . . .20 to .50

" Mermelis................. .20 to .50

" Pachyrrhiza (new) (rare).......... . . .50 to 1.00

" Purpurea................. .20 to .50

“ Radiata................... .20 to .50

" $\quad$ Rufescens. . . . . . . . . . . . . . .20 to .50

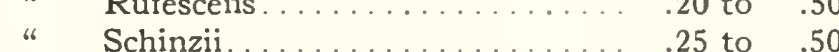

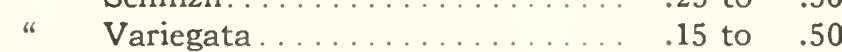

“ Viriabilis................ .25 to .50

“ Zebrina (very rare).............. 1.00

Sedum Pachyphyllum.............. .15 to .35

Sempervivum Atropurpureum. ........ . .15 to $\quad .50$

Haworthia ............... 15 to .25 
